\title{
Wypłacanie subwencji na działalność statutową w sytuacji podziału partii politycznej ${ }^{1}$
}

\begin{abstract}
W sytuacji podziału partii politycznej na dwa (lub więcej) formalnie „nowe" ugrupowania prawo nie przewiduje rozdzielenia subwencji z budżetu państwa na działalność statutową. Nie jest też dopuszczalne przekazanie nowym ugrupowaniom prawa do otrzymywania subwencji przez poprzednią partię. W sytuacji „oddzielenia się" od istniejącej partii politycznej nowego ugrupowania, istniejąca wcześniej partia pozostaje podmiotem praw i obowiązków o charakterze majątkowym, w tym prawa do otrzymywania subwencji na działalność statutową. W sytuacji podziału partii politycznej połączonego z jej rozwiązaniem subwencja jest wypłacana do końca miesiąca, w którym partia podjęła decyzję o „samorozwiązaniu się".
\end{abstract}

Słowa kluczowe: partia polityczna, subwencje

Payment of subsidies for statutory activities when a political party splits: In a situation when a political party divides into two (or more) formally "new" parties, the law does not provide for the division of subsidies from the state budget for statutory activities of the party. It s not acceptable for the new parties to receive subsidies granted to the predecessing party. In a situation of "separation" from the existing political party, the earlier existing party remains a subject of rights and obligations of a financial nature, including the right to receive subsidies for its statutory activity. If a political party is divided and dissolved, the subsidy is paid until the end of the month in which the party decides to "dissolve itself".

Keywords: political party, subsidies

Doktor nauk prawnych, starszy wykładowca na Uniwersytecie Jagiellońskim, ekspert ds. legislacji BAS - piotr.czarny@neostrada.pl • https://orcid.org/0000-0002-6558-1075

\section{Zagadnienia wstępne}

Przedmiotem niniejszej opinii prawnej jest odpowiedź na dwa pytania. Po pierwsze, chodzi o problem: „,czy w przypadku, gdy dojdzie do podziału partii politycznej, w którego efekcie powstaną dwie nowe partie polityczne, dochodzi również do podziału subwencji wyborczej analogicznie do podziału Funduszu Wyborczego". Po drugie - w przypadku odpowiedzi negatywnej na pytanie pierwsze pojawia się dodatkowe pytanie: „co dzieje się z przyznaną subwencją?”.

Mimo że znane są rozwiązania ustawowe dotyczące skutków finansowych połączenia się lub podziału partii politycznych, to żadna z tych regulacji wprost nie

$1 \quad$ Opinia prawna $w$ sprawie wypłacania subwencji na działalność statutowa $w$ sytuacji podziału partii politycznej sporządzona 16 lipca 2019 r. na zlecenie posła Koła Poselskiego Konfederacji; BAS-WAKiU 1186/19. 
odnosi się do sytuacji, której dotyczy postawione pytanie. Jednak wątpliwości wzbudzać może to, czy w ustawie nie występuje luka, która powinna być wypełniona w drodze analogicznego zastosowania tych rozwiązań, w szczególności art. 37 pkt 2 ustawy o partiach politycznych.

Niniejsza opinia została sporządzona przede wszystkim na podstawie przepisów ustawy z 27 czerwca 1997 r. o partiach politycznych (t.j. Dz.U. 2018, poz. 580; dalej: u.p.p.). Uzupełniająco wykorzystano również niektóre postanowienia rozporządzenia Ministra Finansów z 18 lutego 2003 r. w sprawie wypłacania z budżetu państwa subwencji przysługującej partiom politycznym (Dz.U. nr 33, poz. 267).

\section{Uzasadnienie i ustalenia szczegółowe}

Aby odpowiedzieć na przedstawione we wstępie pytania, należy ustalić, co oznacza pojęcie podziału partii politycznej. Nie jest to termin prawnie zdefiniowany, niemniej w literaturze prawniczej wyróżnia się dwie podstawowe jego formy (secesja i separacja). Podział partii politycznej może być skutkiem secesji (rozłamu), co ma miejsce wówczas, gdy część członków partii podejmuje decyzję o opuszczeniu swojego dotychczasowego ugrupowania i utworzeniu nowego ugrupowania. Jednak nie powoduje to zakończenia działalności „partii opuszczonej”. Z kolei z separacją mamy do czynienia wtedy, gdy partia polityczna podejmie decyzję o podziale ugrupowania. Rozstrzygnięcie takie oznacza tym samym zakończenie funkcjonowania partii w dotychczasowym kształcie, dając zarazem początek nowym ugrupowaniom ${ }^{2}$. Warto zwrócić również uwagę, że statuty partii politycznych z reguły milczą w kwestii ewentualnego podziału istniejącej partii politycznej ${ }^{3}$.

Ze sposobu sformułowania pytania cytowanego we wstępie wynika, że chodzi w nim raczej o wymienioną wcześniej separację, mowa bowiem o powstaniu w efekcie podziału dwóch „nowych” partii. Zresztą sytuacja secesji o tyle nie rodzi problemów prawnych, że istniejąca wcześniej partia pozostaje podmiotem praw i obowiązków o charakterze majątkowym, w tym prawa do otrzymywania subwencji na działalność statutową.

Wspomniany podział partii poprzez separację rodzi natomiast istotne problemy natury prawnej. Z jednym wyjątkiem (zob. niżej) nie jest on wprost uregulowany w ustawie o partiach politycznych. Niemniej należy podkreślić, że tego rodzaju zjawisko jest w pełni dopuszczalne, ponieważ poręczona w Konstytucji $\mathrm{RP}$ wolność tworzenia i działania partii politycznych: zakłada również swobodę

2 Zob. M. Serowaniec, Likwidacja, podział i łaczenie partii politycznych $w$ Polsce, „Toruńskie Studia Polsko-Włoskie/Studi polacco-italiani di Toruń” 2016, t. XII, s. 328.

3 Ibidem. 
decydowania o bycie partii, $w$ tym podjęcia decyzji o ewentualnym jej połaczeniu lub podziale ${ }^{4}$. Ustawowy wymóg demokratycznego ukształtowania struktur wewnątrzpartyjnych partii politycznych (art. 8 u.p.p.) powoduje, że wszelkie decyzje związane z podziałem partii powinny pozostawać $\mathrm{w}$ gestii najwyższych organów statutowych partii. W takiej sytuacji zastosowanie powinny znaleźć statutowe uregulowania dotyczące sposobu rozwiązania się partii (art. 9 ust. 1 pkt 9 u.p.p.). Za organ właściwy do podjęcia rozstrzygnięć w tego rodzaju sprawach należy zatem uznać ogólne zebranie członków partii lub zgromadzenie ich demokratycznie wybranych przedstawicieli ${ }^{5}$.

Zasadnicze znaczenie dla odpowiedzi na pierwsze pytanie ma treść art. 28 u.p.p., zgodnie z którym: Partia polityczna, która: 1) w wyborach do Sejmu samodzielnie tworzac komitet wyborczy otrzymała w skali kraju co najmniej $3 \%$ ważnie oddanych głosów na jej okręgowe listy kandydatów na postów albo 2) w wyborach do Sejmu weszła w skład koalicji wyborczej, której okręgowe listy kandydatów na posłów otrzymały w skali kraju co najmniej 6\% ważnie oddanych głosów, ma prawo do otrzymywania przez okres kadencji Sejmu, w trybie i na zasadach określonych $w$ niniejszej ustawie, subwencji z budżetu państwa na działalność statutowa.

Prawo podmiotowe do otrzymywania subwencji oddzielić należy od uprawnienia do kolejnych jej rat, to uzależnione jest bowiem od spełnienia pewnych dodatkowych warunków (zob. art. 34c i 38d u.p.p.). Jednak najważniejsze jest to, że skoro art. 28 ust. 1 u.p.p. wyraźnie określa podmiot uprawniony do otrzymywania (przez okres kadencji Sejmu) subwencji, to przyjąć należy, że zmiana tego podmiotu musi wynikać $\mathrm{z}$ wyraźnych i jednoznacznych postanowień o charakterze szczególnym wobec art. 28 ust. 1. Dopuszczalności tego rodzaju zmian nie można natomiast domniemywać.

Tego rodzaju wyraźne i jednoznaczne regulacje zawiera art. 31 ust. 1 u.p.p., w myśl którego w razie połączenia się partii politycznej z inną partią lub partiami subwencja, o której mowa w art. 28 u.p.p., przysługuje nowej partii w wysokości równej sumie subwencji ustalonych dla łączących się partii. Subwencja ta jest wypłacana na podstawie wniosku złożonego przez właściwy organ nowej partii politycznej, począwszy od miesiąca, w którym sąd dokonał odpowiedniego wpisu w ewidencji. Przepis ten ma (wobec jednoznacznej użytej w nim terminologii) zastosowanie jedynie w przypadku „fuzji” (połączenia) partii politycznych ${ }^{6}$. Ponieważ jest to regulacja szczególna, reguły wykładni wykluczają jej rozszerzającą wykładnię. Również dyspozycji art. 31 ust. 1 u.p.p. nie da się zastosować w drodze analogii do sytuacji podziału partii politycznej, nie ma bowiem wówczas żadnego sumowania się subwencji.

Ibidem, s. 327.

5 Ibidem.

6 Zob. M. Granat, A. Gorgol, J. Sobczak, Ustawa o partiach politycznych. Komentarz, Warszawa 2003, s. 130-131. 
Dodać należy, że wobec treści art. 28 ust. 1 u.p.p. nie można przyjąć, że partia polityczna, która nabyła prawo do subwencji, może przenosić to uprawnienie (ewentualnie uprawnienie do otrzymywania kolejnych rat subwencji) na inne podmioty (inne partie polityczne). Sama subwencja jest świadczeniem na działalność statutową konkretnej uprawnionej partii, nie może być przedmiotem jej dowolnych rozporządzeń majątkowych. Oczywiście po otrzymaniu samej raty subwencji partia względnie swobodnie decyduje o przeznaczeniu wypłaconych jej środków finansowych, ale jest to w sensie prawnym co innego niż dysponowanie samym prawem do subwencji.

Przepisy ustawy o partiach politycznych przewidują swego rodzaju podział kwoty subwencji między partie, które nabyły prawo do subwencji przez udział w składzie koalicji wyborczej (art. 28 ust. 1 pkt 2). W tym wypadku ustawa o partiach politycznych nie jest w pełni konsekwentnie i jednoznacznie sformułowana, bo używa też formuł: „subwencja przysługująca koalicji wyborczej” (art. 28 ust. 2) lub „subwencja dla koalicji wyborczej” (art. 29 ust. 1). Jednak w istocie subwencja może być wypłacana tylko partiom (a nie koalicjom), nie chodzi tu więc o jej podział, a tylko o szczególny sposób obliczenia w takiej sytuacji jej wysokości. Przyjmuje się za punkt wyjścia wysokość subwencji obliczoną dla samej koalicji w taki sposób, jakby była to partia polityczna, a następnie wysokość kwoty rocznej subwencji jest dzielona między poszczególne partie w sposób określony w przedłożonej Państwowej Komisji Wyborczej umowie zawiązującej koalicję wyborczą (art. 28 ust. 2 i 3). Oczywiste jest, że tego rodzaju mechanizm nie może być obecnie zastosowany w odniesieniu do podziału subwencji przysługującej konkretnej partii politycznej w sytuacji innej niż jej przynależność do koalicji wyborczej, której listy otrzymały wystarczający zgodnie z art. 28 ust. 1 pkt 2 u.p.p. procent głosów.

Jak już wspomniano, przepisy ustawowe tylko raz wyraźnie odnoszą się do podziału partii politycznej i jego skutków. Mowa o nim wyraźnie w art. 37 pkt 2 u.p.p., zgodnie z którym: środki finansowe Funduszu Wyborczego partii w razie jej podziału przekazywane są na rzecz Funduszu Wyborczego nowo powstałych partii w częściach równych, chyba że partia - rozwiązując się - ustanowi inne proporcje podziału. Regulacja ta związana jest ze szczególnym statusem tej części majątku partii, który zgodnie z art. 35 u.p.p. należy do stałego Funduszu Wyborczego utworzonego w celu finansowania udziału partii politycznej w wyborach do Sejmu i do Senatu, w wyborach Prezydenta Rzeczypospolitej Polskiej, w wyborach do Parlamentu Europejskiego oraz w wyborach organów samorządu terytorialnego. Fundusz taki ma charakter celowy, tj., po pierwsze, nie można z niego dokonywać wydatków na inne cele, a po drugie, że celów tych nie można finansować z pominięciem Funduszu Wyborczego ${ }^{7}$. Artykuł 37 pkt 2 u.p.p. opiera się w związku z tym na założeniu, że zawarta w nim regulacja ustana-

7 M. Dębska, Ustawa o partiach politycznych. Komentarz, 2013, LEX, uwaga 3 do art. 35. 
wia odstępstwo od zasady celowego charakteru Funduszu Wyborczego. Chodzi o to, że środki z niego mogą zostać przeznaczone na inne cele niż finansowanie kampanii wyborczej, ale tylko w aspekcie podmiotowym - będzie to kampania innej (w sensie formalnym) partii. Z tego względu przepis ten nie powinien być interpretowany rozszerzająco i odnoszony do innych składników majątku partii politycznej, która ulega podziałowi.

Zgodnie $\mathrm{z}$ art. 46 ust. 1 u.p.p. $\mathrm{w}$ razie rozwiązania się partii politycznej na podstawie własnej uchwały właściwy organ partii niezwłocznie przesyła sądowi uchwałę o samorozwiązaniu partii oraz o wyznaczeniu jej likwidatora, a w myśl ust. 2 tego artykułu, jeżeli partia polityczna nie ustanowi, zgodnie z ust. 1, likwidatora, to wyznacza go sąd. W nieuregulowanych w ustawie o partiach politycznych sprawach likwidacji partii stosuje się odpowiednio przepisy rozdziału 5 ustawy z 7 kwietnia 1989 r. - Prawo o stowarzyszeniach (t.j. Dz.U. 2019, poz. 713$)$. W myśl art. 38 prawa o stowarzyszeniach majątek zlikwidowanego stowarzyszenia przeznacza się na cel określony w statucie lub w uchwale walnego zebrania członków (zebrania delegatów) o likwidacji stowarzyszenia, a w razie braku postanowienia statutu lub uchwały w tej sprawie, sąd orzeka o przeznaczeniu majątku na określony cel społeczny. Przyjąć na tej podstawie ogólnie należy, że uprawnione statutowo organy partii mogą zdecydować o przekazaniu majątku rozwiązywanej partii również na rzecz nowo powstałych partii. Jednak na podstawie art. 38 prawa o stowarzyszeniach $\mathrm{w}$ związku z art. 49 u.p.p. partia, która kończy formalnie swoją działalność w związku z podziałem o charakterze separacji, nie może zdecydować o przeznaczeniu na rzecz nowych partii uprawnień, które dopiero ewentualnie nabyłaby w przyszłości. Może ona decydować o przeznaczeniu swojego majątku, tj. przysługujących jej w danym momencie prawach majątkowych. Stąd też nie może przekazać nikomu abstrakcyjnie pojmowanego „prawa do subwencji” ani też do przyszłych jej rat kwartalnych.

Dodatkowo zauważyć należy, że przyjętą w niniejszej opinii interpretację art. 28 ust. 1 u.p.p. potwierdza analiza przepisów rozporządzenia Ministra Finansów z 18 lutego 2003 r. w sprawie wypłacania z budżetu państwa subwencji przysługującej partiom politycznym, a w szczególności wzór urzędowego formularza wniosku o wypłacenie subwencji za dany rok stanowiący załącznik do tego rozporządzenia. Rzecz w tym, że wniosku tego nie da się prawidłowo wypełnić w sytuacji, gdyby podstawą starań o wypłacenie subwencji było to, że dana partia polityczna powstała w drodze formalnego podziału (separacji) partii, która była uprawniona do otrzymywania subwencji. Oczywiście okoliczność ta ma uzupełniające znaczenie, ponieważ zgodnie $\mathrm{z}$ art. 33 ust. 2 u.p.p. wspomniane wcześniej rozporządzenie reguluje: szczegółowy tryb składania wniosku o wypłacenie subwencji, wzór urzędowego formularza wniosku w tej sprawie oraz szczegółowe zasady wypłacania subwencji. Nie można wobec tego na podstawie wspomnianego wcześniej rozporządzenia wiążąco stwierdzać, jakie partie są uprawnione do otrzymywania dotacji, bo to określają przepisy rangi ustawowej. 
Odpowiedź na drugie pytanie zawiera art. 31 ust. 3 u.p.p., zgodnie z którym w przypadkach, o których mowa w art. 45 u.p.p., subwencja przysługująca partii politycznej nie jest wypłacana, począwszy od miesiąca następującego po miesiącu, w którym partia polityczna rozwiązała się lub sąd zarządził jej likwidację. Z kolei art. 45 stanowi, że partia polityczna podlega likwidacji wskutek rozwiązania mocą uchwały uprawnionego statutowego organu partii lub postanowienia sądu o wykreśleniu wpisu partii z ewidencji z przyczyn, o których mowa w art. 20, 21, 39 i 44 u.p.p.

Oznacza to, że w sytuacji samorozwiązania się partii - również w związku z jej podziałem na dwa (lub więcej) nowe ugrupowania polityczne - subwencja na działalność statutową przestaje być wypłacana. To, czy w miejsce rozwiązanej partii powstają nowe ugrupowania polityczne (a nawet to, czy nie przejmują one niektóre składników majątkowych rozwiązującej się partii) nie ma w tym zakresie istotnego znaczenia prawnego. Partia, której statutowo upoważnione organy podjęły uchwałę o jej rozwiązaniu, bezwarunkowo traci prawo do otrzymywania subwencji z budżetu państwa, a - zgodnie z tym, co stwierdzono wcześniej - nie jest dopuszczalne, aby zostało ono przeniesione na inne podmioty, w tym w szczególności na inne partie polityczne. Inaczej mówiąc, prawo do subwencji w takich okolicznościach wygasa.

\section{Podsumowanie}

- W sytuacji podziału partii politycznej na dwa (lub więcej) formalnie „nowe” ugrupowania ustawa o partiach politycznych nie przewiduje rozdzielenia między te ugrupowania subwencji z budżetu państwa na działalność statutową, która przysługiwała partii ulegającej podziałowi. Nie jest też dopuszczalne przekazanie im prawa do otrzymywania subwencji przez samą tę partię (w drodze określenia celu, na jaki ma być przeznaczony jej majątek) ani wypłacanie im subwencji na podstawie ich „własnego” wniosku.

W sytuacji „oddzielenia się” od istniejącej partii politycznej nowego ugrupowania istniejąca wcześniej partia pozostaje podmiotem praw i obowiązków o charakterze majątkowym, w tym prawa do otrzymywania subwencji na działalność statutową.

- Artykuł 37 pkt 2 u.p.p., przewidujący rozdzielenie środków pieniężnych z Funduszu Wyborczego partii politycznej ulegającej podziałowi między nowo powstałe partie, nie ma zastosowania do subwencji na działalność statutową, która przysługiwała tej partii. To samo stwierdzenie odnosi się do przepisów dotyczących podziału subwencji w sytuacji rozwiązania się koalicji wyborczej.

Podobnie nie można stosować tutaj przez analogię przepisów dotyczących połączenia partii politycznych, które przewidują, że nowo powstała partia „przejmuje” prawo do subwencji w wysokości równej sumie subwencji ustalonych dla łączących się partii. 
- W sytuacji podziału partii politycznej połączonego z jej rozwiązaniem subwencja jest wypłacana do końca miesiąca, w którym partia podjęła rozstrzygnięcie $\mathrm{o}$,samorozwiązaniu się". W okresie postępowania likwidacyjnego subwencja nie przysługuje, ponieważ partia nie prowadzi już działalności statutowej. Oczywiście subwencja nie jest też wypłacana w okresie późniejszym, bo z chwilą wykreślenia partii z ewidencji nie ma podmiotu uprawnionego do jej otrzymywania.

\section{Bibliografia}

Dębska M., Ustawa o partiach politycznych. Komentarz, 2013, LEX.

Granat M., Gorgol A., Sobczak J., Ustawa o partiach politycznych. Komentarz, Warszawa 2003.

Serowaniec M., Likwidacja, podział i łączenie partii politycznych w Polsce, „Toruńskie Studia Polsko-Włoskie/Studi polacco-italiani di Toruń” 2016, t. XII, http://dx.doi. org/10.12775/TSP-W.2016.020. 